This article was downloaded by: [University of Sydney]

On: 30 April 2015, At: 08:27

Publisher: Routledge

Informa Ltd Registered in England and Wales Registered Number: 1072954

Registered office: Mortimer House, 37-41 Mortimer Street, London W1T

3J H, UK

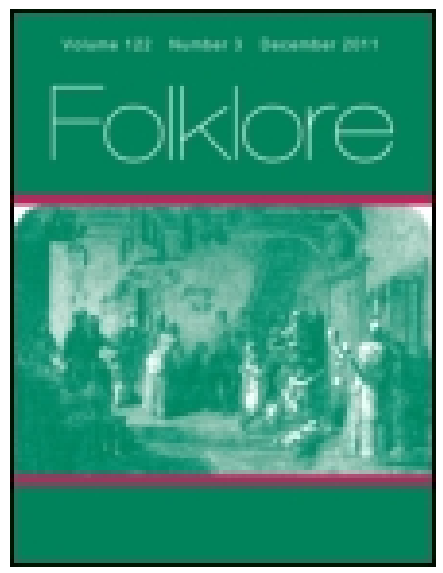

\title{
Folklore
}

Publication details, including instructions for authors and subscription information:

http:// www. tandfonline.com/loi/ rfol20

\section{The Legend of Merlin.}

M. Gaster

Published online: 14 Feb 2012.

To cite this article: M. Gaster (1905) The Legend of Merlin., Folklore, 16:4, 407-427, DOI: $10.1080 / 0015587 X .1905 .9719975$

To link to this article: http:// dx. doi. org/ 10.1080/0015587X.1905.9719975

\section{PLEASE SCROLL DOWN FOR ARTICLE}

Taylor \& Francis makes every effort to ensure the accuracy of all the information (the "Content") contained in the publications on our platform. However, Taylor \& Francis, our agents, and our licensors make no representations or warranties whatsoever as to the accuracy, completeness, or suitability for any purpose of the Content. Any opinions and views expressed in this publication are the opinions and views of the authors, and are not the views of or endorsed by Taylor \& Francis. The accuracy of the Content should not be relied upon and should be independently verified with primary sources of information. Taylor and Francis shall not be liable for any losses, actions, claims, proceedings, demands, costs, expenses, damages, and other liabilities whatsoever or howsoever caused arising directly or indirectly in connection with, in relation to or arising out of the use of the Content.

This article may be used for research, teaching, and private study purposes. Any substantial or systematic reproduction, redistribution, reselling, loan, sub-licensing, systematic supply, or distribution in any form to anyone is 
expressly forbidden. Terms $\&$ Conditions of access and use can be found at http://www.tandfonline.com/page/terms-and-conditions 


\section{THE LEGEND OF MERLIN.}

BY M. GASTRR.

(Read at Meeting, 20th June, 1905.)

ONE of the central figures in the Arthurian cycle is that of the uncanny prophet and magician Merlin. His whole history is surrounded with so much mystery, and so many inexplicable incidents are interwoven in the relation of his birth and his further activity that they have baffled the ingenuity of many a scholar. I now endeavour to make a contribution towards the elucidation of some of the most prominent features of the romance. We must not forget that we are dealing with 2 written and not with an oral literature. The individuality of the author is more pronounced and the personal equation much easier to determine than in the anonymous remnants which have been retained by the memory of the folk Each poem is a literary monument which must be critically examined, in the same way as we are now examining and dissecting every other literary remains of ancient times.

And here the personality of the author ought to occupy the first place. I may not have seen all that has been written on these medizval romances, but as far as I know there is nowhere a critical study of the personality of their authors. We do not find any clear description of their lives and learning, of the circumstances under which they wrote, the influences to which they were 
exposed and the range of knowledge at their disposal. What did they know and how did they know the things of the past, and what kind of knowledge was popular (i.e. acceptable to their readers and listeners)? The atmosphere of a society colours every product and moulds, consciously or unconsciously, the mental activity of the bard and of the poet.

Two or three points deserve our close attention. In the first place, what was the occupation of the authors, especially the authors of the prose romances which we may assume precede every romantic poem? (For the story is first written down, and afterwards taken up by the trouvere and versified, as it is to be sung before the barons at the festive board and later on, when it has become a popular tale or a shorter ballad, among the lower bourgeoisie) The art of writing was in that early period known to but few. The little knowledge which the Middle Ages possessed was almost a monopoly of the clergy. The clerk, as the name denotes, was in most cases a cleric. The historiographers and chroniclers were as a rule monks and priests, and they wrote as often as not for the special edification of those readers and for the praise and honour of those places, with which they stood in close contact. Every clever writer would enhance and extol the virtues of his special saint and of the church devoted to the memory of that saint. His miracles would be retailed to a believing and loving public almost to the exclusion of any other saint, and the worship of the local shrine was thus continued from olden times in a new setting. The clerical authors drew their inspiration from the religious literature with which they lived in daily connection. They saw things only and solely through the glasses of ancient legendary lore and could not find greater praise for their own saints and heroes than to liken them to those that shone to them from the pages of the old books they so much revered 
and whose personages seemed to them the acme of human and divine achievement.

The second point to which I must draw attention is that the records of olden times, of persons and places, were not understood by the people unless translated into their own surroundings, dressed in their garb, speaking their language, and behaving in the same manner as their contemporaries were behaving. The heroes of the Homeric poems, the exploits of Alexander, were viewed from a standpoint of the knight and the tournament. Unless Alexander, or say Ajax and Achilles, accommodated themselves to put on the armour of the knight and to act the way the people acted they would have been ignored. The whole ancient world became a living contemporary; the heroes obeyed the code of chivalry with all its complicated etiquette. One can scarcely recognise the old heroes under the new disguise, and it requires a whole system of reconstruction and rearrangement in order to recognise old acquaintances in the knights of the medixval romances. Yet the difference is one of detail and setting, not of incident or motif. 1

And thirdly, what were the literary methods of these authors? A close investigation of the whole romantic literature reveals, side by side with great poetical force, a surprising poverty of invention. The situations and incidents told of one hero are repeated ad nauseam by every subsequent poet. Nay, whole cycles of romances are bodily taken over and applied to other heroes than those of whom they were originally composed. Too well known to be emphasised again is the transfer of the whole Merovingian cycle to

1 Ilow the new chivalry came to life at that time is a problem with which I cannot deal here, nor is it an easy task to trace its origin to an indisputable source. Suffice it for us to note the fact that the refined form of chivalrous adventures, the beloved theme of the subsequent romantic literature, does not appear in Europe before the end of the eleventh century, and follows as it were in the wake of the Crusades and as a sequel to the exploits in the East and to the close contret with the new world which opened to the Europeen knight. 
the Carolingian. The old kings and knights gave way to new kings and knights, but only the names were changed, the rest remained almost unaltered. The same process of transfer from older and more or less forgotten heroes takes place continually; new names' are substituted for the old, and local considerations play a decisive role in the transfer. The trouvere who sings the exploits of the ancestor of this baron will use the same language and ascribe the same exploits to the ancestor of another baron when he sings in his hall and at his banqueting feast. The same tendency prevails everywhere and at every time. We meet with it at almost every turn in the epical poetry of the East, and of the West. It is one of the constant factors in the development and evolution of the ballads. Sufficient attention has not been paid to this point Here and there this transfer and change has been admitted, but not recognised as an universal law, only as an exceptional incident. I an the contrary find in this practice of constant substitution, the very key to the problem of the sources from which the ancient writers have drawn their inspiration. Their skill consisted in giving a thorough local character to a tale borrowed from elsewhere and in so changing the colouring as to impress their contemporaries and to win their applause.

This, then, is my starting-point in the investigation of the sources of the Merlin legend. Our earliest authority for it is the Chronicle of Geoffrey of Monmouth. ${ }^{1}$ I therefore ask myself:-Given a monk at a local shrine, endowed with some poetical imagination, to what kind of literature could he have had access in England at the end of the eleventh or twelfth century? What mass of tradition could be floating about him, to be caught up and fixed in his writings? and for what kind of audience did he

1 See my article on Tewish Sowness and Parallels to Early English Matrical Romances, $180 \%$. 
write in the hope of appealing to their sentiments and winning their approval? How great was his naivete and their credulity? As for the last there is no limit to either, but as for his learning we must take it as restricted within a very narrow compass. Primarily his mind must have been saturated with Christian religious literature largely composed of legendary matter; the innumerable lives of saints and holy anchorites, the vast apocryphal literature, were the great storehouse of his information and inspiration. The Golden Legend was not only the first book printed by Caxton, but also one of the earliest with which every cloister was familiar. It must also not be forgotten that the Apocrypha found their earliest home in England long before any other country in Europe. The oldest poems of Caedmon and the oldest Mysteries written here go back primarily to these apocryphal tales and legends. The very centre of the Graal legend rests ultimately on these uncanonical writings, modified, no doubt, to some extent by other motives and interpretations of a mystical nature, which again have their root in mediaval Christian mystical speculation upon transubstantiation and the spiritualisation of the Mass and Sacrament.

Can we then find anything in that religious literature which, if stripped of its modern accoutrement and changed into its more primitive form, could be considered as one of the sources for the legends clustering round the name of Merlin ? which may briefly be related as follows:

Vortigern, king of Britain, determined to erect an impregnable castle, in which he might defy all attempts of his enemies. Having made this decision he pitched upon a spot on Salisbury Plain, traced out the plan of the fortifications, sent for artificers, carpenters, and stonemasons, and collected all the materials requisite to building; but the whole of these disappeared in one night, so that nothing remained of what had been pro- 
vided for the construction of the citadel. Materials were, therefore, procured from all parts a second and a third time, and again vanished as before, leaving and rendering every effort ineffectual. Vortigern inquired of his wise men and astronomers the cause of this opposition to his undertaking, and of so much useless expense of labour. They replied : "You must find a child born without a father, put him to death, and sprinkle with his blood the ground on which the citadel is to be built, or you will never accomplish your purpose."

In consequence of this reply the king sent messengers throughout Britain to search for a child born without a father. After having inquired in all the provinces, three out of seven came to the field of Aelecti, in the district of Glevesing, where a party of boys were playing at ball. And two of them quarrelling, one said to the other, " $O$ boy without a father, no good will ever happen to you." Upon this the messengers drew their swords, conceiving they had found what they sought. But Merlin-for he was the boy-after rebuking his companion for his indiscretion, ran to the messengers, and, to their great astonishment, told them the whole circumstances of their mission, assuring them at the same time that Vortigern's wise men were fools, and that all the blood in his veins would not in any way contribute to the solidity of the intended castle. He then conducted them to his mother, who told them the history of his miraculous birth, which is, in short, as follows:-She was one of three sisters, of whom the two first went astray, and she herself was deceived by a (devil) semi-demon in shape of a man. As soon as this was found out she was brought before the Judge to be condemned to death. But St. Blaise, her confessor, believed her, and interfered in her favour to postpone the judgment until two years after the birth of the child. When that event took place St. Blaise baptised it immediately, and counteracted the wicked purposes of 
the devil. After a time, when the mother was bewailing her fate, the new-born child opened his mouth, and said to his mother, "Be not dismayed, for you shall never be judged to death for my cause."

When the two years were expired, she appeared in court with her child in her arms, when, to the astonishment of all, the infant undertook her defence. He then proceeded to tell that he was the son of a devil of great power, though fortunately rescued by an expeditious baptism from the vicious dispositions of his paternal relations; that he could prove his preternatural descent by revealing all things, past, present, or future. And at the same time he told the Judge some very unpleasant truths about his own descent, which convinced him of the prophetic power of Merlin and of the innocence of his mother. Five years after this, by the advice of Merlin, she assumed the veil of a nun, and spent the remainder of her life in acts of devotion.

Merlin was just seven years old when he was met by the messengers, who, at his entreaty not to shed his blood, promised to spare his life, and they decided to bring him alive to Vortigern.

The journey lasted three days, and each of these added to the admiration of the messengers for their young companion. I will mention here only one of his acts. They passed the first night in a market town, the streets of which were crowded by merchants; and here Merlin after a long silence, burst into a sudden and violent fit of laughter. On being questioned about the cause of his mirth, he pointed out to the messengers a young man who was bargaining for a pair of shoes with uncommon earnestness. And he said: "See you not that young man that has shoon bought, and strong leather to mend them ? He thinks that he will live them to wear; but, by my soul, I dare well swear he will be dead before he enters his gate." The event immediately followed 
the prediction. So also, in two other cases, his prophecies came true.

When he knew of Merlin's arrival, Vortigern rode forward to meet him in great magnificence. The following day Vortigern conducted the child to the site of his projected castle Merlin, before answering, wished to be confronted with the astronomers who had thirsted for his blood, and asked them why they had counselled the King to slay him. At the same time he revealed to them that they dreaded him, and that they feared he might cause their death if he should live, and therefore they had devised to kill him. He then asked the permission of the King to question them as to the cause of the destruction of the castle, and why it could not be built; and requested that if they should not know it, whilst he did so, he might then do with them what they thought to do with him. The King consented to every thing he asked, and the astronomers felt abashed, and declared humbly that their art had certainly deceived them, but the signs seen in the heavens could not admit another interpretation. They also did not know the cause of the tumbling down of the walls. Merlin proceeded then to say that immediately below the soil were two deep pools of water; below the water two huge stones, and below the stones two enormous serpents, the one white as milk, the other red as fire; that they slept during the day, but regularly quarrelled every night, and by their efforts to destroy each other occasioned an earthquake which demolished the building. Merlin ordered the workmen to dig away the earth. The water was soon discovered, and, by sinking wells, was wholly drawn out. The two stones were found at the bottom, and being removed, exhibited the tremendous serpents, which looked like fiends of hell. The struggle between the two began, and ended with the victory of the white serpent, which, however, disappeared after the combat. Merlin explained 
the symbolical meaning of this fight, and this forms his famous prophecy, composed or versified by Geoffrey of Monmouth, which forms now the eighth book of his History. It was delivered by a child, and remained obscure until to-day.

To start at once with the final result which it will be my duty to prove, Vortigern and Merlin are here the late and somewhat confused outcome of a more ancient Oriental tale which belongs to the cycle of King Solomon and Ashmedai or Asmodeus. The history of Jovinian in Gesta Romanorum, ${ }^{1}$ compiled in the thirteenth century, offers us also one side of that same cycle and shows that the series of legends connected with Solomon had already reached Europe some time before and had become completely assimilated by the writers of the Middle Ages, following the principles of transformation I have sketched above. The differences between the oldest version of the Solomon story and that of Geoffrey show unmistakably that the form only reached Geoffrey after it had undergone many a change in the course of time, for only after the belief in the Incubus had taken deep root in the minds of the people could such an origin as that of Merlin be believed in. In a former stage another origin would be ascribed to the wonderful child. We find one of these intermediary stages in a remarkable book, in which is related the legendary history of Jesus ben Sira, the author of the collection of wise sayings which forms part of the biblical Apocrypha.? This legendary biography agrees in the main with the child history of Merlin. Almost every incident is found there, naturally differently set, but all the vital points are there. His mother is the daughter of the prophet Jeremia and the latter is his father in a miraculous manner. One can easily detect that either name is there of a late origin and has been

\footnotetext{
1 Ed. Oesterley (Berlin, 1872), No. 59, p. 360.

Alphnbetum Pseudo-Sirncidicum, ed. S. Seinschmeider (Berlin, 1858), f. 168 , sq.
} 
substituted for another now effaced. In the Slavonic version of the history of the Sibylla, ${ }^{1}$ we find another parallel to this peculiar miraculous birth. She is the daughter of King David begotten in a supernatural way, and this origin explains in both cases the ulterior prophetic wisdom of the offspring. (Incidentally I remark here that the Sibylla has been identified with the Queen of Sheba.) In the latter case the child becomes the prophesying Sibylla, and in the former the history goes on to tell marvellous adventures which bring the Sira story in closer similarity still to the Merlin legend. For Sira or Sirach speaks to his mother immediately after birth and comforts her, protecting her against the abuse of the world, almost with the same words as used by Merlin, who also protects his mother and proves her innocence. Sira's wisdom spreads far and wide and excites the envy and animosity of the astrologers and magicians at the court of king Nebuchadnezzar. They decide therefore on his destruction, and induce the king to send armed messengers to bring him, and to put to him such questions as he would be unable to answer; and thus hope to compass his death. The messengers find him, and after some trouble bring him to the king. He is then just seven years old, exactly the same age as Merlin when he appears before King Vortigern. At the court he easily discomfits his adversaries and causes their death instead of his by means of clever riddles. After that a discussion arises between the king and the child, who answers all the questions put to him, as well as cures the daughter of the king who is suffering from a strange disease. He then remains as the trusted counsellor of the king. His further fate is left as mysterious as his birth, and no mention of his death occurs.

We have in this legend a late and modified version of a much older tale, in which the principal actors are on the

$2 V$. Gaster, Liberatura populara romana (Bucureati), p. 338; L. Milietich Stomikstre (Sofia, 1893), vol ix, pp. 177-180. 
one side King Solomon, whose place has been taken here by Nebuchadnezzar, who is already turned to a kind of buffoon, and on the other a demon, whose place has been taken by a wonderful child with prophetic powers and of a half-human and half-demoniacal nature. ${ }^{1}$ This version proves that at the end of the seventh century (for I place the date of the history of Sira at that period), the old legend had undergone sufficient change to approximate it to the legend of Merlin. But we must assume the existence of a fuller text of this form of the legend in which some of the older incidents had been preserved which have dropped out of the Sira version. In the old Solomon version we find the following incidents, which occur again in the Merlin version but not in the intermediate one of Sira. Solomon is anxious to build the Temple, but must not use any iron for cutting the stones. The only person that can help him is the king of the demons, Ashmedai, whom his general Benayah captures by a clever trick and who fastens a chain round him upon which the ineffable name of God had been engraved, so that he could not. break it. On the way to the king the demon meets a bridal pair, and he weeps; he sees a wizard prophesying and promising to others riches, and he laughs; he sees a man bargaining for a pair of shoes and asking whether they would last him for seven years, and again he laughs; and so he does many strange things until brought before King Solomon, where he continues to act in a similar manner. When asked a few days later to explain the reason of his weeping at a bridal procession and his merriment at the man asking for a pair of shoes that would last a long time,

\footnotetext{
2 It is not bere the place to discuss a possible and very plaurible connection between this version of the legend and other legends current at that and at earlier times, in Asia, about the vingin birth. Suffice it to remark that in the infant history of Jesus the won of Sirach we find surprising parallels to the apoeryphal "Gospel of the Infancy," notably in the incidents of the precocions child and the teacher, which child instead of being tanght takes the rolu of the teacher.
} 
he replies that in the former case the bride would die soon, and that the buyer of shoes which are to last for seven years would not complete seven days. ${ }^{1}$

I pass over other incidents which do not touch our question. It is only important to notice the strange behaviour of the demon and the dialogue which follows between him and the king. This later portion has been influenced afterwards by other legends of such witty dialogues and the putting of riddles to Solomon, or by Solomon to other reputed clever people, and is the ultimate source of the whole cycle of Solomon and Morolf,or Saturn and Marculph. The legend related by Josephus" of the riddles put by Solomon and King Hiram through Abdemon may have contributed to introduce a demon into the legend. The Queen of Sheba, who is the hero of other witty contests with King Solomon, according to widely spread Oriental legends, partakes also of the character of a demon or a genie. She has the feet of a demon, and is thus half human and. half demoniacal, and she is also identified later on with the prophesying Sibylla. This form is then transplanted into the next development of the legend in Europe, of which we have the Romance of Solomon and Morolf in German and the still more important Slavonic version of Solomon and Kitovras, which Vesselofsky in his exhaustive study of this cycle of legends has proved to be a corruption from Kentauros, the half-human half-animal creature of Greek mythology. The contest then is between Solomon and a being which in consequence of the Christian colouring could no longer be a heathen Kentauros, but follows the lines of the Sirach version, and becomes a child in which the demoniacal half is represented by the father and not by the actual semi-human form.

1 Talmed; Treat. Güken, f, 68.

Gaster, Lit. pop, p 79, ff

'Josephus, Amtiz., viii., 53.

1A. N. Vesselorsty, O Solomene i Küoomas (St. Petersburg, 1872), 
How did this old legend then come over to England? No doubt in one of those collections of religious legends and tales which formed the library of the cloister, and reveal clearly the atmosphere in which the writers of those times moved. Their scholarship could not be very extensive, and we must therefore try and find the sources of such legends in such books as could be within the reach of the writers of the age. I need not again emphasise the fact that in the so-called Gesta Romanorum (which, according to Oesterley, the greatest authority on the subject, were first collected in England), we find other stories of the Solomon cycle.1

I will now give, in as faithful a translation as I can command, a legend which I have found in an old Rumanian manuscript, embedded among miracles of the Virgin Mary and of St. Nicholas. It will prove, I hope, the existence of the missing link between the Oriental tale and the Western Christian counterpart and indicate the way and the possibility how such legends could have become known to the monks in the West. The tale in itself I consider a gem from a purely poetical point of view, and were it not that I bring it forward in this connection I intended publishing it separately as one of the most beautiful tales I have found among the Exempla and Gesta of old.

The tale (in my MS. $7 \mathrm{I}$ ) is called: "How it came to pass that the Archangel Gavriil served an abbot for thirty years," and is as follows:

" Once upon a time it came to pass that the Lord sent the Archangel Gabriel to take away the soul of a widow woman, and, going there, he found her near death and two

2 Such as the contegt of Solomon with the demon Asmodens and his obtaining the miraculous stone-cutling worm Tamir or Shamir (so already In Petrus Comestor's Historia Scholastica and in other writers, such as Vincent of Beauvain, etc); the humbling of Solomon through this very demon, Solomon being changed into King Jovinian. To this cycle belong also the "Angel and the Hermit," inculcating similar moral teaching. 
twins were suckling at her breasts. The angel seeing it took pity upon them and returned without having carried out His command, not having taken the soul of the widow. This happening he was asked by the almighty power of God, why he had done so. He replied, ' For the sake of those two children I did not take the soul of their mother.' Then the Lord told him to plunge into the depths of the sea and to bring up a stone from the bottom. When he brought it up the Lord told him, 'Cleave it in twain.' And the Archangel cleft the stone and he found therein two little worms. 'Who feeds these worms inside the stone at the bottom of the sea?' asked the Lord. And Gabriel replied, 'Thine abundant mercies, $O$ Lord I' And the Lord said, 'If mine abundant mercies feed these worms inside the hard rock, how much more would I feed the children of men whom I have saved with my own blood!' Whereupon He sent another angel to take the soul of the widow, and the Archangel he condemned to serve for thirty years as servant to an Abbot and to take care of him, and at the end of the thirty years he was to receive the soul of that Abbot and carry it up to the throne on high. And thus the Archangel became the servant of the Abbot, and during all the time he was very humble and meek and obedient, so that the Abbot marvelled at him and all through those thirty years no one saw him laugh. One day the Abbot said to him, 'My son, go and buy me a pair of shoes which are to last one year.' He then laughed. The Abbot, who did not know that the serving brother was an angel, wondered at it, and he sent another brother with him to watch whether he would laugh again. So the other followed him and they came to a place where a poor man sat who cried, 'Give alms, have pity on me,' and the angel laughed again. They met afterwards a carriage In it sat the bishop and the governor of the town with great pomp and pride and many people following after them. And the angel turned aside 
and laughed again. In the market place they saw a man stealing an earthenware pot and the angel laughed a fourth time. After they had finished their purchase they returned to the Abbot and the other brother told the Abbot that he had laughed three times more. Then the Abbot asked the angel and said, 'What can this be, what does this mean, my son? For thirty years thou hast been serving me and I have never seen thee laugh, and to-day thou hast laughed no less than four times.' And the angel replied, 'I am the Archangel Gabriel and I was once sent by the Lord to take the soul of a widow whom I found suckling two children at her breast; taking pity on them I spared her, and as punishment for this my doing have I been sent by the Lord over all to serve thee thirty years and to protect thee from all evil, and at the end of the thirty years I am to receive thy soul Now the thirty years have come to an end and I will then tell thee the reason for my laughing. I laughed first when thou didst order me to buy thee a pair of shoes which were to last for a year, whilst thou hast barely three days more to live. I laughed a second time when I heard the beggar asking for alms whilst he was sitting on a rich treasure without knowing it. I laughed for a third time when I beheld the bishop and the governor riding about with so much pomp and pride, for these were the twins of the widow on whose behalf I had been punished, and for a fourth time did I laugh when I saw clay stealing clay. And this is the reason why I laughed. But do thou now prepare thyself, for the time of our journey has arrived.' The Abbot, hearing these words prepared himself and on the third day he gave up his soul to the Archangel who took it with him on high, where he joined his heavenly band rejoicing. Amen."

Thus far this wonderful tale, full of deep faith and moral beauty, with its impressive lesson of divine providence and not wanting in human pathos and poetry. 
You will observe that one of the incidents which cause the angel to laugh is absolutely identical with the incident in the legend of Merlin, and as I have already pointed out forms part of the older version of the Solomon Ashmedai cycle. The Rumanian story goes back, as does all Rumanian religious literature, either directly, or indirectly through Slavonic intermediaries, to a Greek source, and from thence it could have reached England at an early period, sufficiently early to form part of the literary repertory of the church or cloister. By means of this religious literature the legends of the East travelled and found a ready home in the West.

But there are still incidents in the life of Merlin which require elucidation. He is forcibly summoned before the king because he is to explain the reason of the falling of the foundations of the new castle. The suggestion of the magicians to sprinkle the foundations with his blood reminds one forcibly of similar devices and legends in the East and in the West. They go back to the practice of human sacrifices which have been practised far and wide and have not yet entirely died out, though in modern times the shadow is immured in the foundation in the belief that the person whose shadow is laid in the foundation of a house is sure to die within the year of the erection, and he would then be the protecting genius of the house I know this practice as a living one in Rumania, where the gipsies, who are the bricklayers, try to take the measure of the shadow of any person that passes by and build it into the foundation.

More important is the solution of the riddle by Merlin, who orders the builders to dig up the foundations, where they would find two dragons fighting one another, and sure when thus liberated to destroy another and thus remove the cause of the constant falling in of the walls. There is a curious old legend connected with the building of the Temple according to which when they dug for 
the foundations they came upon the waters of the deep, which surged up and threatened to drown the world, until the advice was given to David (Solomon) to write the wonder-working name of God upon a stone and to place it upon the mouth of the waters of the deep. They would sink and the stone would close the orifice and thus save the world.1 Yet another legend is current in Europe, due to the teaching of the Elucidarium, that curious handbook of the Middle Ages into which all the natural science of the period with all its fantastic embellishments flowed, and from which many a scholar of the time drew his information about the phenomena of nature. We are told there, in the cosmography of the world, that the earth rests upon water, the water upon a mighty rock, the rock upon two whales, and when these whales move there is an earthquake. There is yet another source, and this approaches the Merlin legend too closely not to be considered the true source of the history of the two fighting dragons. This also is found in a book with which every priest in olden and modern times might be expected to be quite familiar, for it is nothing else than the famous dream of Mordecai in the Apocryphal additions to the book of Esther. The passage in question runs as follows: I am giving here the rendering of the more elaborate Aramaic version (De Rossi), ${ }^{2}$ corresponding to XI, 5-II Greek. "Behold there was a great noise and tumult and the voice of terrible uproar upon the whole land and terror and fear seized all the inhabitants of the earth; and behold there appeared two mighty dragons and they came one against the other to fight and all the nations of the earth trembled at the noise of their fury. And there was a small nation between

1 Talmed; Treat. Succel, f. 53 a, 8.

J. B. De Rosi, Spac. Var. Cect. at Chald Essteris addimenta, ed. a (Tisteriog 1783), P. 122 f. 
those two dragons and all the nations of the earth rose up against it to swallow it up. And there were clouds and darkness and obscurity upon the face of the earth . . . and the dragons fought one another with cruel fury and frenzy and no one separated them. And Mordecai beheld and $10 !$ a fountain of living water sprang and flowed between the two fighting dragons and stopped their fight. And the small fountain swelled into a mighty river and overflowed like a mighty sea and swept everything off the face of the earth. And the sun rose up and the rays lighted up the whole earth"

Here we have the floods at the bottom of the castle and the two fighting dragons. The small nation may be represented by the small child. The interpretation by Mordecai of that symbolical dream, just as Merlin interprets afterwards the appearance of these two fighting dragons and their symbolical meaning for the future of the house of Vortigern, and the Sibylla, Sheba, prophesies the future when leaving King Solomon.

Let us now briefly sum up the results at which we have arrived. A king is engaged in the building of an important house (temple, castle). He cannot carry it out without the assistance of a being endowed with supernatural powers (a demon, a half-and-half human and demoniacal being, a child born under extraordinary circumstances and endowed with supernatural wisdom). This being helps the king in his undertakings and defeats the machinations of its enemies (the demon becomes the friend, wife, of the king); the cause of the trouble is found in unquenchable floods or in dragons shaking the foundation; the cause is laid bare and the event is invested with a symbolical meaning (a prophetic utterance), foretelling the future. On the way to the king the supernatural being acts in a curious and apparently unaccountable manner, but in the end his wisdom and foreknowledge is vindicated by subsequent events. All these elements the 
Merlin legend has in common with the Oriental traditions which cluster originally round Solomon and which have been elaborated in the course of time and in many recensions, the latest of which stands nearest to the Merlin legend.

What then is more natural than to assume that these latest versions lie at the bottom of the legend as elaborated in England by Geoffrey or any of his immediate predecessors, who had, as we have seen, ready access to these masses of legends and tales. They are an essential and highly prized part of the vast religious legendary material, that formed the storehouse of information in those times. Given the practice of assimilating old legends to new surroundings and spelling the past in the letters and ideas of the present, of substituting better known names for less known ones and making a romance out of the ancient tales of Greece and Palestine, then this legend can only be the reflex of the oriental tales and motives, not even skilfully worked up. One can easily detect the seams in the coat The latter part of the Merlin legend entirely belies the first. There is absolutely no connection between the later adventures of Merlin at the courts of Vortigern, Uter, and his son, and the incidents at the beginning of the tale.

The Lives of the Saints and the tales of pious anchorites, the Bible with its apocryphal additions, suffice completely to explain the origin of the legend and I therefore do not see why we should go outside the immediately possible and probable and venture upon hypothetical assumptions of Celtic or other tales, the existence and higher antiquity of which have still to be proved. Above all it must be shown how any religious writer came to know of such legends and mythical tales, which to his eyes must have appeared as heathen abominations, which he was bound to suppress and to banish, being the work of the Evil Spirit, and not to be supported by his religious zeal 
and devotion. I do not wish to exclude the possibility of some lay trouvire introducing later on into the versified poem some other trait of a local origin, and embellishing his tale with elements drawn from different sources, but the proof for this must first be adduced and the premisses from which I started must not be lost sight of nor slightingly pushed aside. Not only must we take cognizance of the atmosphere in which poets and romancers moved, but also recognise that the same forces which act in modern times operated also in those days. A man can only be the product of his time, he cannot soar far above the limitations of education and surroundings. If in order to understand a poet we must go to the poet's land, so also must we go to his library, to his spiritual armoury, to know whence he has taken his spiritual weapons. The genius of the poet does not shine so much in what he says as in how he says it, how he transfigures the elements with which he deals. $\mathrm{He}$ is the true alchemist who changes the base metals of spurious and wondrous tales into the gold of immortal poems. Out of simple apocalyptic visions of Heaven and Hell grew the immortal poem of Dante, and from very inferior Italian novels some of the most beautiful dramas of immortal Shakespeare. Lesser geniuses have transformed older Oriental tales into romances of chivalry, religious tales into phantastic compositions which delighted the masses of the mediæval public, prone to listen to everything supernatural and wondrous, not over-critical nor fastidious about the fare placed before them, and satisfied to get a glimpse of another world of men greater and braver and nobler than themselves, and of learning, indistinguishable at the time from witchcraft, by means of which the future could be read as easily as the past, and the dark powers that surrounded them could be subdued and made to serve the best and highest interests of kings and nations.

M. GASTER. 


\section{NOTE ON THE ABOVE.}

I CANNOT agree with Dr. Gaster's theory that the prose romances preceded, and were the sources of, the poetical. The main body of expert opinion inclines to the other view; i.e. that hais and metrical romances preceded, and were elaborated into, the longer prose works. Of the authors of these prose works we know nothing; it is doubtful whether Walter Map, to whom the majority of them has been described, ever wrote anything of the lind. M. Gaston Paris has shown that Helie de Boron and Lucas de Gast, the reputed authors of the Tristan, are merely assumed names. Such biographical details as Dr. Gaster sighs for are in the present state of our knowledge quite unattainable.

Nor is there any reason to believe, save in the case of the Grand Saint Graal and Queste, that the author of any one of these romances was a monk Nor were the monks unfamiliar with secular traditions. They were not born and bred in the cloister, but in many cases came thither after a long experience of court and camp. Why should they have forgotten what they knew in the world?

With regard to the Merlin story, Layamon, who certainly had access to insular and local traditions, gives a very different account of his birth. His father was no "demon," but a glorious golden-clad knight, who appeared to his mother in a dream. The story discussed by Dr. Gaster only touches a very small part of the Merlin-legend. It affects nothing in his later life and offers no parallel to the shape-shifting which was so marked a feature of his career; nor for his "wood-abiding" madness and his prophecies. It is quite as likely that a sage of his fame should have been fitted with a birth-story drawn from a world-wide tradition, as that the whole Merlin story should have sprung from such a tradition. All that Dr. Gaster can claim is to have shown that his birth-story is based upon a tradition not specifically insular, but world-wide, and of great antiquity.

JESSIE L. WeSTON.

[See further, p. 462.] 